\title{
A SYNOPSIS OF THE CAVE MILLIPEDS OF THE UNITED STATES, WITH AN ILLUSTRATED KEY TO GENERA*
}

\author{
By William A. Shear \\ Museum of Comparative Zoology, Harvard University
}

\section{INTRODUCTION}

The taxonomy of the Class Diplopoda is presently in a chaotic and undeveloped state, even in an area so well-studied for most organisms as the United States. Attempts by the uninitiated to identify collections of even the most common forms of millipeds are usually thwarted by the lack of keys and revisions in the literature, and specialists in this group are frequently swamped with requests for determinations from ecologists, museums, general collectors and speleobiologists. Cave explorers have made a great contribution to our knowledge of the milliped fauna of the United States, with the result that the hypogean forms are usually better known than epigean ones.

At least in the United States, it seems unlikely that additional representatives of new families and genera of millipeds will be discovered in caves, and therefore the time seems ripe for a synopsis of our knowledge of troglobitic diplopods. Causey (I96ob) summarized the features characterizing a milliped as a troglobite, though all sorts of gradations may be obtained within a given family from troglobite through troglophile to cave accidental. In general, pigmentation and the number of ocelli, if these are usually present in the family, are reduced in troglobites. The antennae and legs are longer in proportion to their thickness than in related epigean species and the body segments themselves may be elongated and narrowed. Calcification of the cuticle is often reduced. The dorsal ornamentation so characteristic of many of the families of millipeds is usually suppressed, though in at least one case (Pseudotremia, Cleidogonidae), some highly cave-adapted species are more ornamented than epigean ones. Troglobitic millipeds are frequently a little larger than their epigean relatives, though in some cases (Pseudotremia; Cambala, Cambalidae) troglobites are much smaller. Speostriaria (Striariidae) and Tetracion (Order Callipodida, family name uncertain) are the giants of their respective families in North

Published with the aid of a grant from the Museum of Comparative Zoology.

*Manuscript received by the editor May 6, 1969 
America; in the Trichopetalidae, Scoterpes (to $8 \mathrm{~mm}$ ) is larger than Trichopetalum (4-5 $\mathrm{mm})$.

Troglobitic millipeds undoubtedly evolved under a combination of two major factors: their preadaptation for the cave habitat as a part of the humus fauna, and the climatic fluctuations of the Quaternary. This will be further discussed in a forthcoming revision of the Conotylidae.

Zoogeographically, the troglobitic millipeds present an interesting picture. Pseudotremia, which I am currently revising in connection with a larger study of the family Cleidogonidae, has more than 40 species in the Appalachian region from Alabama north to Indiana and northeast West Virginia. These fall into three groups: those which are clearly troglobitic, with, in some cases, a virtual absence of pigment and ocelli; a group of troglophiles, lightly pigmented and with 25-30 ocelli in each eyepatch; and a small number of very large epigean species with dark pigment and 35 or more ocelli in each eyepatch. The epigean species are mostly found at higher elevations, or associated with known glacial relict areas. The troglobites, for reasons not presently clear, are separated into two groups, one in an arc from extreme northwest Georgia and northeast Alabama through central Tennessee and Kentucky to Indiana, and a second enclave in western Virginia and eastern West Virginia. Endemism is remarkably high; two caves only a mile apart and in the same stream valley in DeKalb Co., Tennessee, have different species of Pseudotremia.

In contrast to this pattern of a widespread genus with highly endemic species are two other kinds of situations. A single species, Cambala speobia, ranges over an area of 2500 square miles in the Edwards Plateau in Texas; Antriadesmus fragilis is known only from a single cave in a well-collected area.

The ecological postion of cave millipeds is uncertain. Like all troglobites, they are ultimately dependent upon importation of food into the cave ecosystem from the outside. The most frequent ecological note with collections of troglobitic millipeds indicates that the specimens were found on rotting wood. I have examined the foreguts of individuals of five species of Pseudotremia and found that wood tracheids were the only identifiable remains. I have also observed a West Virginia species of Pseudotremia feeding on paper, candle wax, raccoon feces and a dead salamander. Tetracion jonesi Hoffman can be baited with carrion; a related epigean genus, $A b a$ cion, is at least partly carnivorous. In turn, cave millipeds may serve as food for cave crickets and salamanders; I have seen Pseudotremia 
specimens taken from the stomach of the cave salamander, Eurycea lucifuga.

The identification of millipeds is founded mostly on the shape of the male gonopods, modified legs found on the seventh segment of mature males. Classifications have been based on these structures to the extent that even some related families cannot be separated if only females and immature specimens are available. The gonopods are often small and retracted into pockets in the body; dissection is usually necessary to identify species. An attempt is made here to present a key to genera based on nonsexual characters that can be observed under low magnification. However, adults should be used; adult males can be recognized by the prominent reduced and specialized legs on the seventh segment, and females have slightly protruding genital valves at the base of the second legs (Figs. 2, 8, I0). With some experience, most specimens can be placed in the appropriate genus. Following the key are notes on the described species in each genus. The identification of species is still a matter for the specialist, most of whom are eager to do such work. Complete references are to be found in the checklist of Chamberlin and Hoffman (1958).

This study was based entirely on specimens, both types and general material, in the Museum of Comparative Zoology. I thank Dr. H. W. Levi for his cooperation and help, and Mr. Stewart Peck for many unpublished data.

\section{Key to Genera}

ra. Adults with no more than 20 segments Order POLYDESMIDA, 5.

Ib. Adults with 28 or more segments 2.

2a. Body of 28 or 30 segments; each segment with six prominent macrosetae Order CHORDEUMIDA, Io.

2 b. Body of more than 30 segments; segments without macrosetae, or with more than six 3.

3a. Body segments with elaborate and regular surface sculpturing of raised ridges or pyriform lobes; the largest of these bearing the pores of the repugnatorial glands (Figs. I, 2)

3 b. Segments with no more than a few low striations, mostly lateral; repugnatorial pores inconspicuous (Fig. I4)

Order JULIDA, Family Nemasomatidae, 20.

4a. First segment overlapping the head; gland openings on rounded lobes; ocelli usually in a single row, or absent (Fig. I)

Order SPIROSTREPTIDA, Family Cambalidae, Cambala. 
4b. First segment not overlapping the head ; gland openings on flattopped ridges; ocelli usually in a triangular group (Fig. 2) ....

Order CALLIPODIDA, Family ?, Tetracion.

5a. Dorsal surface set with rows of small, seta-bearing knobs, three to five rows per segment; 20 segments (Figs. 3, 4)

Family Vanhoeffenidae, 7 .

5b. Dorsal surface of each segment with distinct polygonal areas, each with a small seta; or quite smooth; I9 or 20 segments

6a. Nineteen segments; dorsal surfaces with polygonal areas (Fig. 5) Family Polydesmidae, Brachydesmus.

6b. Twenty segments; each segment smooth

Family Nearctodesmidae, Ectopodesmus.

7a. Segmental setae in five rows Speorthus.

7 b. Segmental setae in three rows

\section{8.}

8a. Paranota (lateral "wings" on each segment) small, rounded (Fig. 3)

8b. Paranota of each segment prominent, sharply produced backward

9.

9a. Last segment triangular, slightly curved ventrad; Nevada ... Tidesmus.

9b. Last segment truncate, not curved (Fig. 4) Texas

Speodesmus.

Ioa. Head partially concealed by the hoodlike first segment; last segment three-lobed; body with IO-I2 more or less prominent ridges that run the length of each segment (Fig. 12)

Family Striariidae, I6.

Iob. Head completely exposed; last segment not lobed; body without ridges as described above, though other surface sculpturing may be present

I Ia. Dorsal surface of segments with a heavy pattern of tiny, sharp ridges; macrosetae inconspicuous (Fig. 9)

Family Tingupidae, Tingupa.

I Ib. Dorsal surface of segments smooth, except for six seta-bearing tubercles, or with rough granulations or knobs, but never sharp, tiny ridges (Figs. 8, IO, I3) I2.

12a. Segmental setae not on prominent knobs, body with nearly smooth margins when seen dorsally ${ }^{1}$.... Family Caseyidae, I 7 .

I2b. Segmental setae on prominent knobs and/or shoulders ....... I3.

${ }^{1}$ Specimens of the eastern genus Cleidogona will key out here; see notes on Cleidogonidae. 
I3a. Dorsal surface of segments coarsely granular or with irregular large tubercles; lateral shoulders prominent on midbody segments (Figs. IO, II, I3)

Family Cleidogonidae, Pseudotremia.

I3b. Dorsal surface smooth between the seta-bearing knobs ........ I4.

I4a. Pigmented specimens from Idaho caves, with more than Io ocelli Family Idagonidae, Idagona.

I4b. If from caves in Idaho, then not pigmented and with less than Io ocelli; if pigmented, then from other localities I5.

I5a. Ocelli in a triangular patch or two subparallel rows; adults usually longer than $12 \mathrm{~mm}$; antennae long, reaching posteriad to the sixth or seventh segment (Fig. 8)

Family Conotylidae.

I5b. Ocelli in a crescent-shaped or right-angled row, or completely absent; adults usually less than $9 \mathrm{~mm}$ long; antennae short, reaching posteriad to third segment

Family Trichopetalidae, i 8.

I6a. Body pigmented; to $20 \mathrm{~mm}$ long

Striaria.

I6b. Body white except for ocelli; to $30 \mathrm{~mm}$ (Fig. I2)

I7a. Without ocelli

Speostriaria.

I7b. With I2-I 4 ocelli

Speoseya.

I8a. Twenty-eight segments; with ocelli

Opiona.

I8b. Thirty segments; no ocelli

Trichopetalum.

19a. Segmental setae nearly as long as segments are wide; Missouri, Illinois, Kentucky, Tennessee, Alabama, Georgia (Fig. 7)

Scoterpes.

I9b. Segmental setae little more than one-half as long as segments are wide; Virginia, West Virginia; eastern Kentucky (Fig. 6)

Zygonopus.

20a. Sixty to 8 o segments (Fig. I3)

Zosteractis.

2ob. Thirty-five to 45 segments

Ameractis.

\section{Notes on Genera \\ ORDER POLYDESMIDA}

None of the members of this order have ocelli, and if they undergo several molts in a cave, they may also become depigmented. However, except for Ectopodesmus, all known true troglobites in this order are no more than $20 \mathrm{~mm}$ long. All troglobitic polydesmids known to me are also narrower than surface forms; the width of Ectopodesmus is only about I/Io its length. The large, heavily pigmented members of the families Polydesmidae and Xystodesmidae 

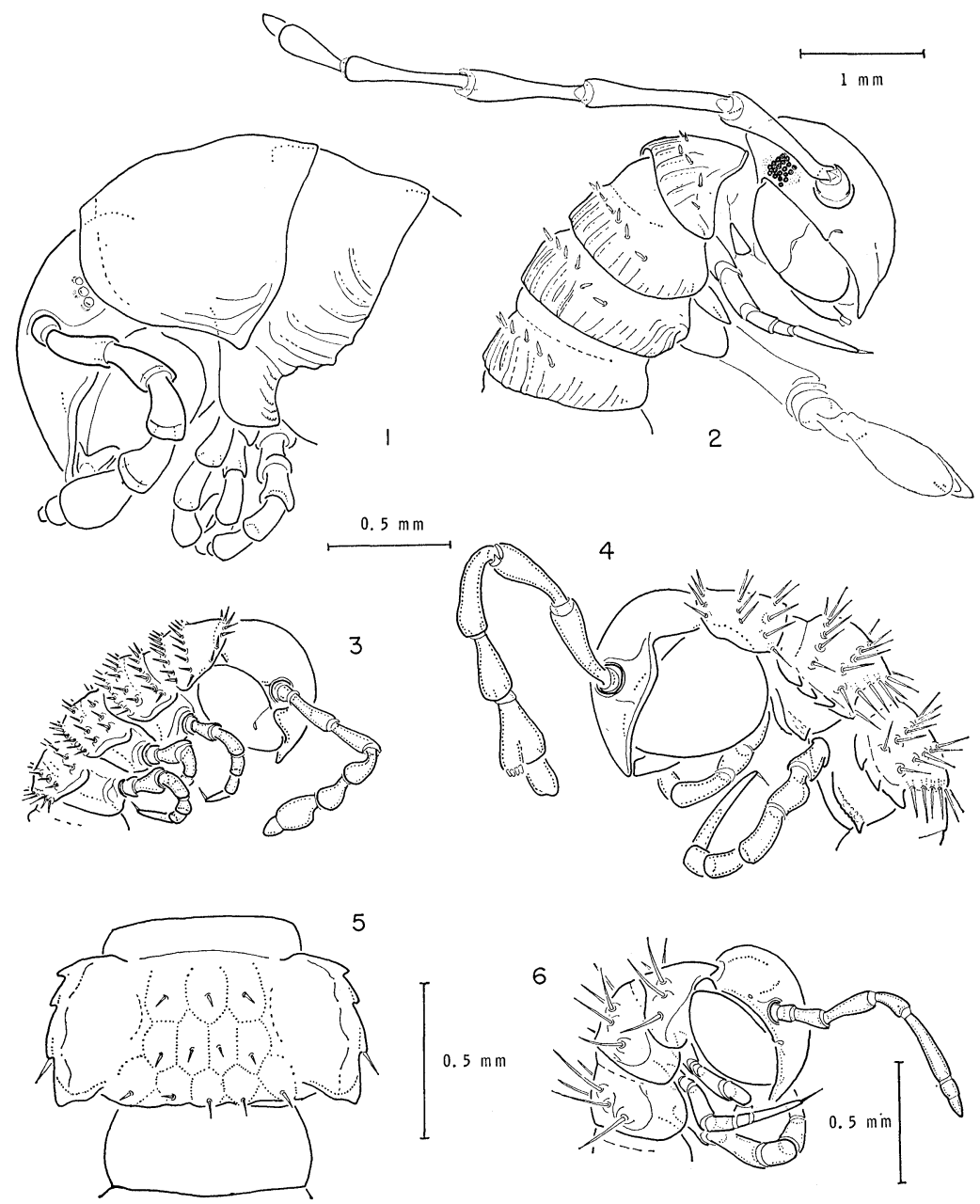

Figs. 1-6. Lateral and dorsal views of anterior ends and body segments of cave millipeds. Fig. 1. Cambala minor. Fig. 2. Tetracion jonesi, female with ovipositor. Fig. 3. Antriadesmus fragilis. Fig. 4. Speodesmus echinourus. Fig. 5. Dorsal view of midbody segment of Brachydesmus superus. Fig. 6. Zygonopus packardi. 
are frequently accidental in caves in the Appalachians, but in the midwestern region, the Family Euryuridae is more common.

\section{Family Polydesmidae}

The limit between this family and the one which follows is not well drawn, and a thorough study is needed to determine which of our North American genera belong here or in other families. At present, none of the North American Polydesmidae seem to be truly troglobitic, and only one genus is significant as a troglophile.

\section{Genus Brachydesmus Heller}

Some of the numerous European members of this genus are true troglobites, but the species which American diplopod systematists for the present assign to the genus are at most troglophilic. Brachydesmus pallidus Loomis ( I939) has been recorded from caves in Virginia and West Virginia, but it is a synonym of $B$. superus Latzel (Fig. 5; holotype of pallidus in Museum of Comparative Zoology, examined) a European epigean and troglophilic species common in cultivated areas of the United States.

Polydesmus cavicola Packard (1877) was placed arbitrarily in Brachydesmus by Chamberlin and Hoffman (1958), who noted that the type was not known to exist. A careful search of the collections of the Museum of Comparative Zoology resulted in the rediscovery of the female holotype. It has 20 segments and three rows of prominent setigerous tubercles, and is thus excluded from Brachydesmus. The general appearance would place it in the 'Family' Vanhoefeniidae (it will key to Tidesmus in the key above), in which case it will probably require a new generic name, but the systematics of the small North American polydesmoids are so confused that I hesitate to add yet another name to the list. It seems clear, however, that the genus Brachydesmus is not well represented in North America.

\section{Family Vanhoeffeniidae Attems Map I}

Chamberlin and Hoffman (1958) and Loomis (1960) have both pointed out that the use of this family name is questionable. However, it is generally agreed (Loomis, I960) that the following genera belong together, whatever the family name might finally become. Causey (1959b) states that Antriadesmus is troglophilic rather than troglobitic, but no surface collections of this genus are known to me. It is easily confused with the humicolous surface form Chaetaspis, of which it may indeed be a synonym. Undoubtedly numerous spe- 


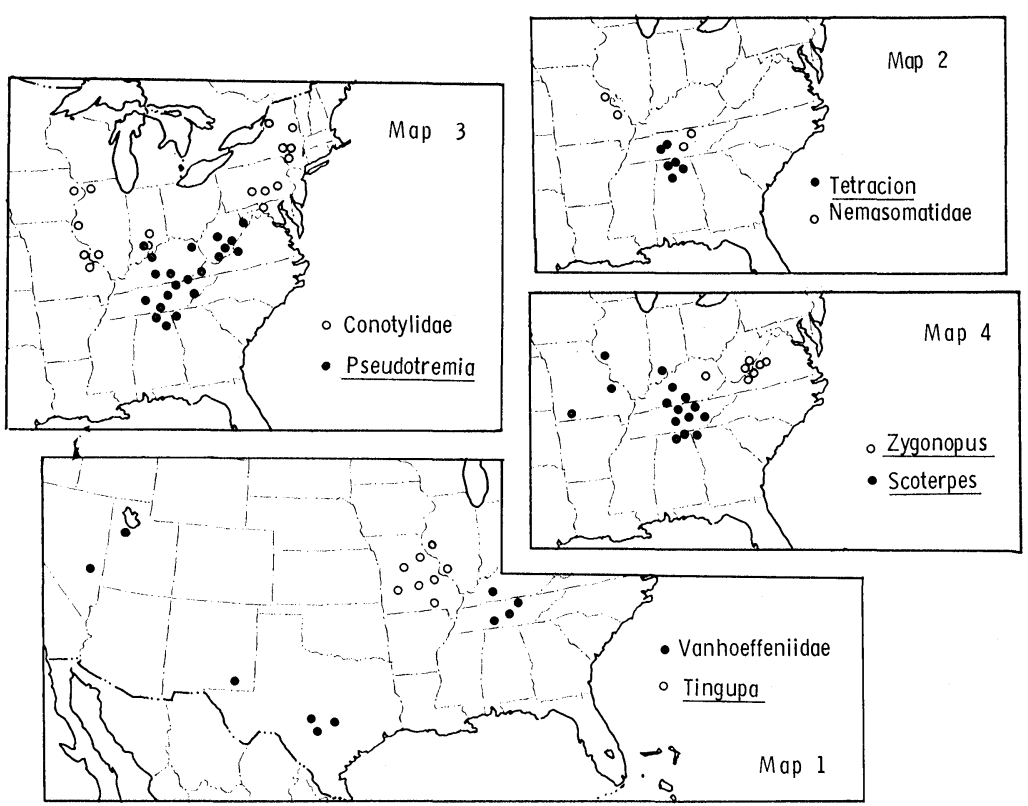

Maps of selected localities of cave milliped collections in the United States. Map 1. Distribution of Tingupa pallida and troglobitic and troglophilic members of the Family Vanhoeffeniidae. Map 2. Distribution of the genus Tetracion and troglobitic members of the Family Nemasomatidae. Map 3. Distribution of the genus Pseudotremia (includes some epigean records) and troglophilic members of the Family Conotylidae. Map 4. Distribution of the genera Scoterpes and Zygonopus.

cies remain to be discovered, particularly in the Southwest and Pacific regions.

\section{Genus Antriadesmus Loomis}

Fig. 3

Three species of this genus are known from the Appalachian region. All are about $6.5 \mathrm{~mm}$ long and can be separated only by the form of the male gonopods, and for the present, the collection locality. Antriadesmus fragilis Loomis (Fig. 3) was described from females (Loomis, 1953) collected in White's Cave, Mammoth Cave National Park, Kentucky; subsequently Loomis (1960) illustrated the male gonopod, and noted that the species occurs nowhere else in the entire Mammoth Cave complex. Causey (1959b) described $A$. mollis from Cumberland Caverns, Warren Co., Tennessee, and $A$. debilis from Walker Spring Cave, Wayne Co., Tennessee. 


\section{Genus Speodesmus Loomis}

Fig. 4

Causey (I959a) has already noted the remarkable loose-jointed appearance of the members of this genus, due to the elongated legs and body segments. They are undoubtedly troglobites. The two known species can only be separated by reference to the male gonopods. Both are found in caves of the Edwards Plateau of Texas. Speodesmus echinourus Loomis (Fig. 4) is known from caves in Kerr and Hays Counties (Loomis, I939; Causey, I959a); S. bicornourus Causey from Beck's Ranch Cave, Williamson Co. (Causey, 1959a). Both species are considerably larger than the preceding genus, being $12-20 \mathrm{~mm}$ long, and they have much more prominent paranota, the posterior angles of which are drawn out posteriad.

\section{Genus Speorthus Chamberlin}

The single species of this genus, S. tuganbius Chamberlin, was described incompletely and without illustration (Chamberlin, I952), but Loomis (1960) subsequently located and illustrated the male holotype. Although tuganbius is only $8 \mathrm{~mm}$ long, the gonopods look very much like those of Speodesmus, and it is quite likely that this name is a synonym of Speodesmus. It is known only from the types, collected in 1924 in Carlsbad Caverns, New Mexico.

\section{Genus Tidesmus Chamberlin}

It is clear from the description given by Chamberlin (1943) of the type species, $T$. episcopus, an epigean species, that Tidesmus $h u b b s i$, described in the same paper, is not a member of that genus, and perhaps not even a member of the same family. The illustrations of the gonopods of episcopus are quite similar to those of members of the genus Phreatodesmus (Loomis, I960). Thus Tidesmus, the older name, may eventually become the proper name of the species now grouped under Phreatodesmus. Only a study of the type material, now unavailable, will solve this kind of problem, common in diplopod taxonomy. But for the present, I will only note that Tidesmus hubbsi was described from the cave of Cave Valley, Lincoln Co., Nevada.

\section{Family Nearctodesmidae Chamberlin and Hoffman Genus Ectopodesmus Hoffman}

The single species of this genus, E. remingtoni Hoffman, was originally described from an unnamed cave I.7 miles north of Grafton, 
Jersey Co., Illinois ${ }^{2}$ (Hoffman, 1962). Subsequent collections have shown it to be not uncommon in many of the caves of western Illinois, particularly in Adams, Pike, and Monroe Counties (S. Peck, pers. comm.). Its closest relatives occur in the Pacific Northwest, thus presenting another instance of the close faunistic correspondence between the Ozark-Appalachian system and the Pacific coast mountain ranges. The case of $E$. remingtoni is remarkably similar to that of the antrodiaetid spider genus Atypoides, with a single species in Missouri and Illinois and two in California and Oregon (Coyle, 1968). Missouri caves should be thoroughly searched for nearctodesmids.

\section{ORDER SPIROSTREPTIDA}

Family Cambalidae

The criteria for the establishment of genera in this family are as yet uncertain. Loomis (1938) recognized several genera, most of them from the western United States, without resorting to details of the gonopod structure. More recently, Hoffman (1956) established the genus Troglocambala, for specimens from Turk's Cave, Conecuh Co., Alabama, separated from Cambala by the three-jointed telopodite of the anterior gonopods. Causey (1964) implied without explanation that this genus was a synonym of Cambala, but established at the same time the genus Mexicambala, also a troglobite, based on specimens from Cueva de la Parra, San Luis Potosi, on differences of a similar quality. Until a thorough study reveals the true relationships of species in this family, it is my opinion that both these genera should be regarded as synonyms of Cambala.

\section{Genus Cambala Gray}

Fig. I

In the eastern United States, both Cambala annulata (Say), a large (up to $45 \mathrm{~mm}$ long), black species, and C. minor Bollman (Fig. I), a small (up to $20 \mathrm{~mm}$ long) brown species are troglophilic. The status of $C$. minor and a few other names based on similar forms is uncertain. Specimens from widely scattered caves in Alabama, Tennessee, Kentucky and West Virginia which I have recently examined show small but constant differences in the gonopods, ocelli number, and pigmentation. Careful study will probably reveal that more than one species is involved.

Cambala loomisi (Hoffman) has already been mentioned; it is the type species of Troglocambala. In Texas, the caves of the Edwards

${ }^{2}$ Now known as Grafton Cave. 
plateau have several species that are perhaps troglobitic; $C$. reddelli Causey is known from Culbertson, Wheeler, and Childress Counties, C. speobia (Chamberlin) from a long list of counties in central and southwest-central Texas (Causey, I964).

\section{ORDER CALLIPODIDA}

Hoffman and Lohmander (1964) use this name for the order usually called Lysiopetalida in this country. The family name of the North American genera is uncertain.

\section{Genus Tetracion Hoffman Map 2; Fig. 2}

Tetracion is represented by two species, $T$. jonesi Hoffman (Fig. 2), in the Tennessee River drainage in northeastern Alabama, and T. tennesseensis Causey (1959a) in Warren and Grundy Counties, Tennessee, in the Cumberland River drainage. Hoffman (1956) described two subspecies of $T$. jonesi from widely separated caves. Since that time, large series of specimens collected by carrion baiting in caves from the intervening localities have come into the collections of the Museum of Comparative Zoology. I have studied this material in detail and have come to the conclusion that the distinction between $T . j$. jonesi and T. $j$. antraeum cannot be maintained, because of the indistinct gradation between the two type localities. Relatively few specimens of $T$. tennesseensis have been collected, but it seems distinct in range and in structure, being somewhat smaller than $T$. jonesi.

\section{ORDER CHORDEUMIDA}

According to Causey ( $1960 \mathrm{ob}$ ), fully $80 \%$ of the troglobitic millipeds of North America fall in this order. Its members are easily distinguished from all others by the presence of six prominent macrosetae on each segment.

\section{Family Conotylidae Cook Map 3; Fig. 8}

Two genera with troglophilic members occur in the eastern United States. Conotyla has two species known primarily from caves, $C$. bollmani (McNeill) of Indiana (Fig. 8), and C. blakei (Verhoeff) of New York, Pennsylvania and Maryland. Austrotyla specus (Loomis) is a troglophile of Missouri, Illinois, and Iowa. Conotyla pectinata Causey, of northern Illinois, represents a third distinct troglophilic genus, and Conotyla humerosa Loomis, a fourth genus containing the only real troglobites of the family. The details of 
these generic assignments and their names will appear in my forthcoming revision of the family. There are numerous epigean species.

\section{Family Idagonidae Buckett and Gardner}

Genus Idagona Buckett and Gardner

Idagona westcotti has been described in detail by Buckett and Gardner (1967) from material collected in two caves in Clark and Butte Counties, Idaho. However, the family is closest to the Conotylidae, which is completely unrelated to the Cleidogonidae, rather than near both these families, as they suggest. The affinities of the Conotylidae and related families are primarily Asian, while the Cleidogonidae are a uniquely American group. Superficially, members of the Idagonidae cannot be distinguished from conotylids, but the outline of a segment (Buckett and Gardner, 1967, Fig. 4) shows that Idagona is somewhat deeper-bodied than the sympatric conotylids.

\section{Family Trichopetalidae Verhoeff}

Two genera, Scoterpes and Zygonopus, are the most modified troglobitic millipeds of North America. Causey ( I963) gives a key to all known genera of the Trichopetalidae.

\section{Genus Trichopetalum Harger}

Members of this genus seem to have remarkably wide distributions, especially for such fragile humus-dwelling animals. Close study of geographic variation may show that numerous species are involved. Trichopetalum is generally considered troglophilic, though one species, T. subterraneum Causey, is known only from Slack's Cave, Scott Co., Kentucky (Causey, 1967).

\section{Genus Scoterpes Cope \\ Map 4; Fig. 7}

Causey (1960b) has identified 27 taxa in this genus, most of them as yet unnamed, presumably differing in details of the male gonopods. Because of their small size (to $8 \mathrm{~mm}$ ) they are frequently overlooked by collectors, but are now known to occur in many caves in Missouri, Illinois, Kentucky, Tennessee, Alabama, and Georgia. Chamberlin and Hoffman list the four described species, of which one (S. austrinus Loomis) is illustrated here (Fig. 7).

\section{Genus Zygonopus Ryder}

Map 4; Fig. 6

Zygonopus is found in caves in eastern West Virginia (Z. packardi 

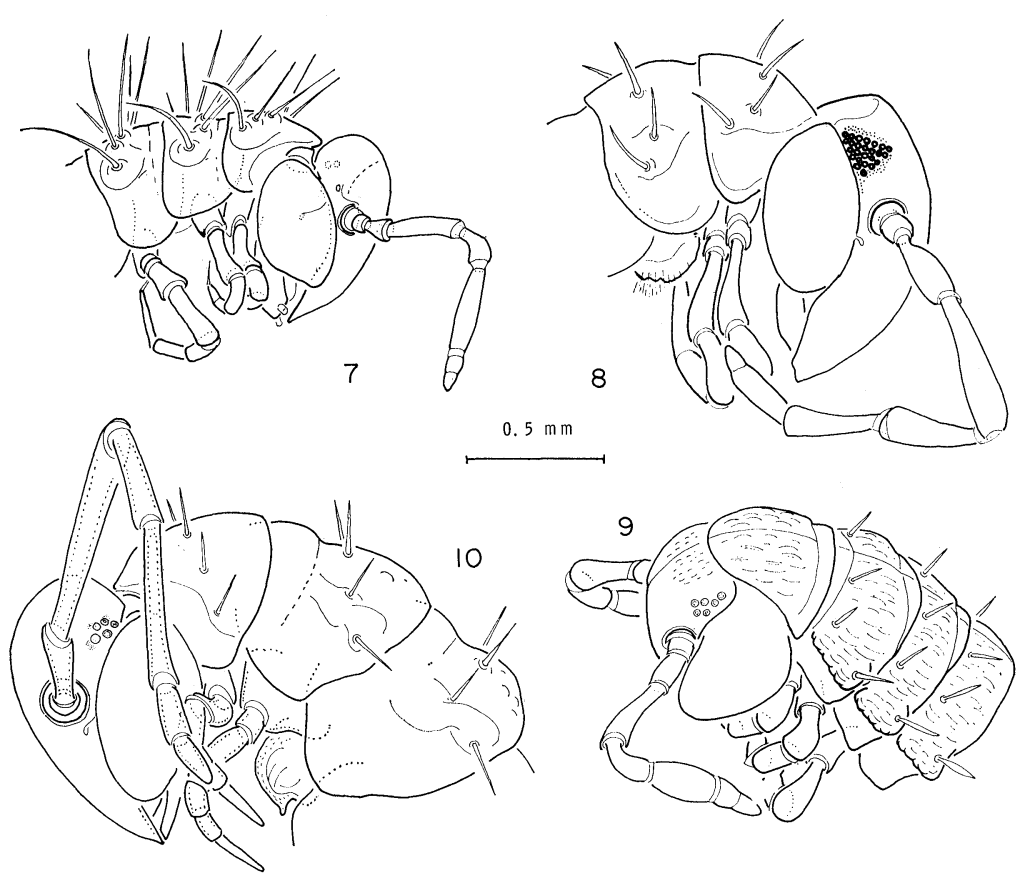

12
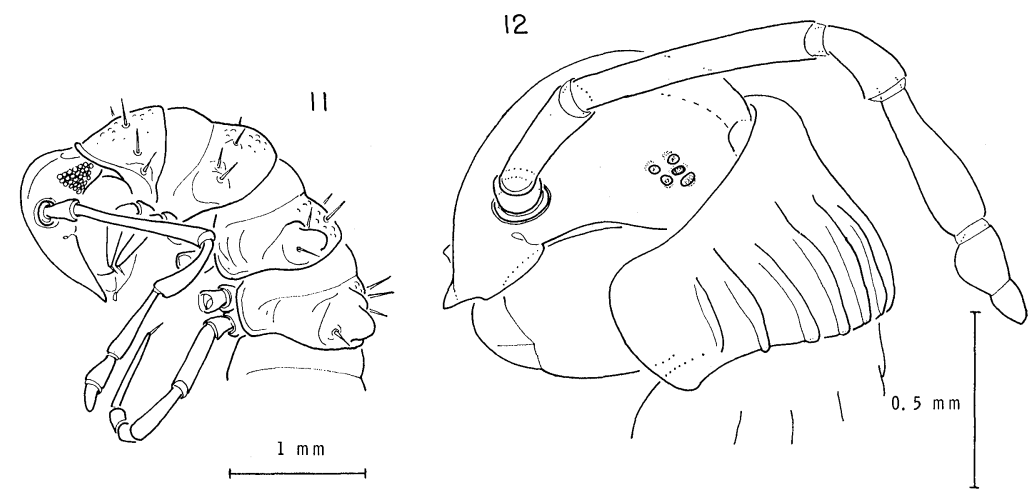

Figs. 7-12. Lateral views of anterior ends of cave millipeds. Fig. 7 . Scoterpes austrinus. Fig. 8. Conotyla bollmani. Fig. 9.Tingupa pallida. Fig. 10. Pseudotremia nodosa. Fig. 11. Pseudotremia hobbsi. Fig. 12. Speostriaria shastae. 
Causey, Fig. 6) and adjacent western Virginia. A single Kentucky record is questionable. Zygonopus seems more distinct from Trichopetalum than is Scoterpes, and the two genera probably had independent origins. Despite a recent revision by Causey (I960a), the status of the four described species remains uncertain: ". . . the four species I formerly assigned to it $\left[Z_{y g o n o p u s}\right] \ldots$ are two species, of which one is composed of three subspecies (Causey, 1963b)."

\section{Family Caseyidae Verhoeff}

This family is poorly known, but probably has many species in the Pacific Northwest and California. Causey (1963a) has done much to clarify the anatomy of the gonopods. The relationship of this family to the small, eastern Family Underwoodiidae needs study.

\section{Genus Speoseya Causey}

Speoseya grahami Causey, the only known species of this genus, is about Io mm long and is known from caves in Calaveras Co., California (Causey, 1963a).

Genus Opiona Chamberlin

Opiona siliquae Causey (r963a), from Fault Rock Cave, Mendocino Co., California, is about the same size as Speoseya grahami, but has ocelli. Two additional epigean species of this genus are known from Washington and British Columbia (Chamberlin and Hoffman, I958).

\section{Family Cleidogonidae Cook}

This is a very large family, distinguished by its large, well-defined genera and relatively wide range (from Ontario to Guatemala). Members of the genus Cleidogona are sometimes found in the Appalachian region as accidentals or troglophiles, ${ }^{3}$ and will key out as caseyids in my artificial key, but the two groups are not sympatric no caseyids occur in the eastern United States.

\section{Genus Pseudotremia Cope}

Map 3; Fig. IO, II, I3

Dearolfia Loomis (1939) is a synonym of this genus. Pseudotremia is the most widespread and abundant genus of American cave millipeds, and has troglobitic, troglophilic and epigean members. Examination of several large collections and of all type material, including

\footnotetext{
${ }^{3}$ There are numerous undescribed troglobitic Cleidogona spp. in Mexico.
} 


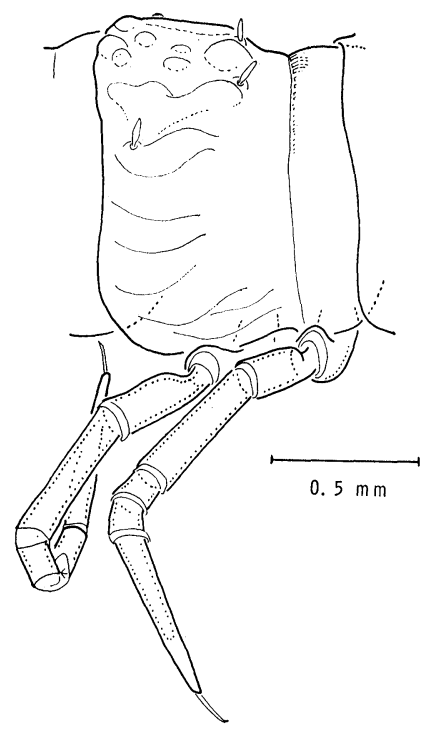

13

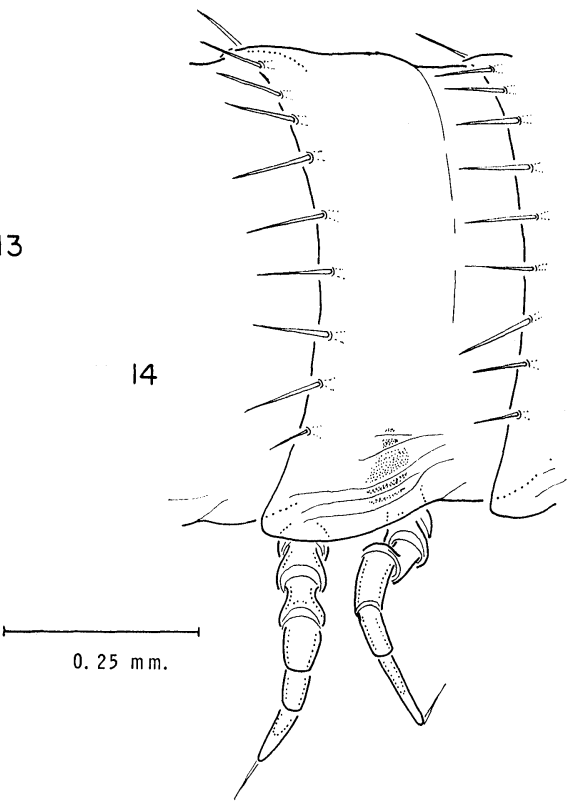

Figs. 13-14. Lateral views of midbody segments of cave millipeds. Fig. 13. Pseudotremia nodosa. Fig. 14. Zosteractis interminata.

that of Packard's species, recently found in the Museum of Comparative Zoology, has shown that there are at least 45 taxa represented. many of them known only from single caves.

The appearance of the true troglobites is strikingly different from that of the other species; the troglobites are usually almost completely without pigment, less than $20 \mathrm{~mm}$ long, with depigmented and reduced ocelli (represented in some cases by only the cuticular lenses) and strongly knobbed segments (Figs. IO, I3). In a series of increasingly larger epigean forms, the lateral shoulders of the segments become more prominent, but the dorsum is not as knobby (Fig. II ). Strenuous efforts should be made to collect males wherever this genus is discovered. They are easily separated from the females by the prominent sclerotized gonopods on the seventh segment.

Family Tingupidae Loomis

Epigean members of this family are known from California, Utah, and Arizona. 
Genus Tingupa Chamberlin

Map I ; Fig. 9

Tingupa pallida Loomis is the only known troglobite in this genus. It occurs in Missouri and Illinois and is about $5 \mathrm{~mm}$ long (Loomis, I939, I943, 1966).

Family Striariidae Bollman

Epigean species of the Striariidae are widely distributed, but seem to be concentrated in the Pacific Northwest. Two genera are known from caves.

Genus Striaria Bollman

Striaria columbiana Cook has been reported from Allen's Cave, Front Royal, Virginia (Loomis, 1939, footnote on p. 186), and $S$. eldora Chamberlin was described from Crystal-Cosumnes Cave, E1dorado Co., California (Chamberlin, 1953). Both may be troglophiles, though $S$. columbiana might better be regarded an accidental for the time being.

\section{Genus Speostriaria Causey}

Fig. I2

Speostriaria resembles Striaria but is nearly half again as large (30 mm long), depigmented, and has fewer ocelli (Fig. 12). The single species, $S$. shastae (Causey), is known only from Samwel Cave, Shasta Co., California (Causey 1958, 1960c).

\section{ORDER JULIDA \\ Family Nemasomatidae Bollman \\ Map 2; Fig. I4}

Hoffman (1964) has done much to clear up the status of the American members of this family, but hesitated to include Zosteractis, usually placed in the family Zosteractiidae. Study of holotype material (Museum of Comparative Zoology) indicates that his inference (1964) was correct, and Zosteractis is herewith included in the family Nemasomatidae.

\section{Genus Zosteractis Loomis}

Fig. I4

The single species of this genus, $Z$. interminata Loomis, (Fig. I4) is known from caves in Missouri and Illinois (Loomis, I943; Causey, I96od). It is about $20 \mathrm{~mm}$ long, but only slightly more than $0.5 \mathrm{~mm}$ wide. 


\section{Genus Ameractis Causey}

Ameractis satis Causey has been recorded from White, Overton, Putnam and Hamilton Counties, Tennessee (Hoffman, I964; Causey, I959b). It is only half the length of Zosteractis interminata and has fewer segments.

\section{Literature Cited}

BucketT, J. S., ANd M. R. Gardner

1967. A new family of cavernicolous millipedes with the description of a new genus and species from Idaho (Diplopoda: Chordeumida: Chordeumidia). Michigan Ent. 1(4): 117-126.

Causey, N. B.

1958. New records and descriptions of a new genus and a new species of millipeds from the family Striariidae (Chordeumida). Proc. Biol. Soc. Washington 71: 179-184.

1959a. Two new troglodytic millipeds from Texas. Proc. Biol. Soc. Washington 72: 69-74.

1959b. Some cavernicolous millipeds from the Cumberland Plateau. J. Tennessee Acad. Sci. 34(4): 229-237.

1960a. The troglobitic milliped genus Zygonopus (Chordeumida: Conotylidae: Trichopetalinae). J. New York Ent. Soc. 68: 69-80.

1960b. Speciation in North American cave millipeds. Amer. Midl. Natur. 64(1): 116-122.

1960c. Speostriaria, new genus (Diplopoda: Chordeumida: Chordeumidea: Striariidae). Proc. Biol. Soc. Washington 73: 25-28.

1960d. Troglobitic millipeds of Missouri. Missouri Speleol, 2(3): 60-65.

1963a. Two new caseyid millipeds from California (Chordeumida: Chordeumidea). Wasmann J. Biol. $21(2)$ : 193-198.

Causey, N. B.

1963b. Mexiterpes sabinus, new genus and new species, a Mexican troglobite (Diplopoda: Trichopetalidae). Psyche 70(4): 235-239.

1964. New cavernicolous millipeds of the family Cambalidae from Texas and Mexico. Internat. J. Speleol. 1(1-2): 237-246, Pl. 58, 59.

1967. Trichopetalum subterraneum, new species from Kentucky, new records and a key to the genus (Diplopoda: Chordeumida: Trichopetalidae). Proc. Biol. Soc. Washington 80: 117-122.

Chamberlin, R. V.

1918. Four new western diplopods. J. Ent. Zool., Pomona Coll. 10(1) : 9-11.

1930. On some centipeds and millipeds from Utah and Arizona. PanPacific Ent. 6(3): 111-121.

1941. New American millipeds. Bull. Univ. Utah, Biol. Ser. 6(4) : 1-39.

1943. On nine North American polydesmoid millipeds. Proc. Biol. Soc. Washington 56: 35-40.

1952. Three cave-dwelling millipeds. Ent. News 63(1): 10-12. 
Chamberlin, R. V. and R. L. Hoffman

1958. Checklist of the millipeds of North America. Bull. U.S. Nat. Mus. 212: 236 p.

Coyle, F. A.

1968. The mygalomorph spider genus Atypoides (Araneae: Antrodiaetidae). Psyche 75 (2): 157-194.

HofFMan, R. L.

1956. New genera and species of cavernicolous diplopods from Alabama. Geol. Surv. Alabama Mus. Pap. 35: 13 p.

1962. A new genus and species in the diplopod family Nearctodesmidae from Illinois (Polydesmida). Amer. Midl. Natur. 68 (1) : 192-198.

1964. Taxonomic notes on some American nemasomatid Diplopoda. Trans. Amer. Ent. Soc. 89: 165-182.

HOFFMAN, R. L., AND H. LOHMANDER

1964. The Diplopoda of Turkey. Parts I and II. Mitt. Hamburg Zool. Mus. 62: 101-151.

Loomis, H. F.

1938. Cambaloid millipeds of the United States, including a family new to the fauna and new genera and species. Proc. U.S. Nat. Mus. $86(3043): 27-66$.

1939. The millipeds collected in Appalachian caves by Mr. Kenneth Dearolf. Bull. Mus. Comp. Zool. 86(4) : 165-193.

1943. New cave and epigean millipeds of the United States, with notes on some established species. Bull. Mus. Comp. Zool. 92(7): 373-410, Pl. 1.

1960. Millipeds of the order Polydesmida from the western states and Baja California. J. Kansas Ent. Soc. 33: 57-68.

1966. Two new families and other North American Diplopoda of the Suborder Chordeumida. Proc. Biol. Soc. Washington 79: 221-230. Packard, A. S.

1877. On a new cave fauna in Utah. Bull. U.S. Geol. Geogr: Surv: Terr. 3 : 157-169. 

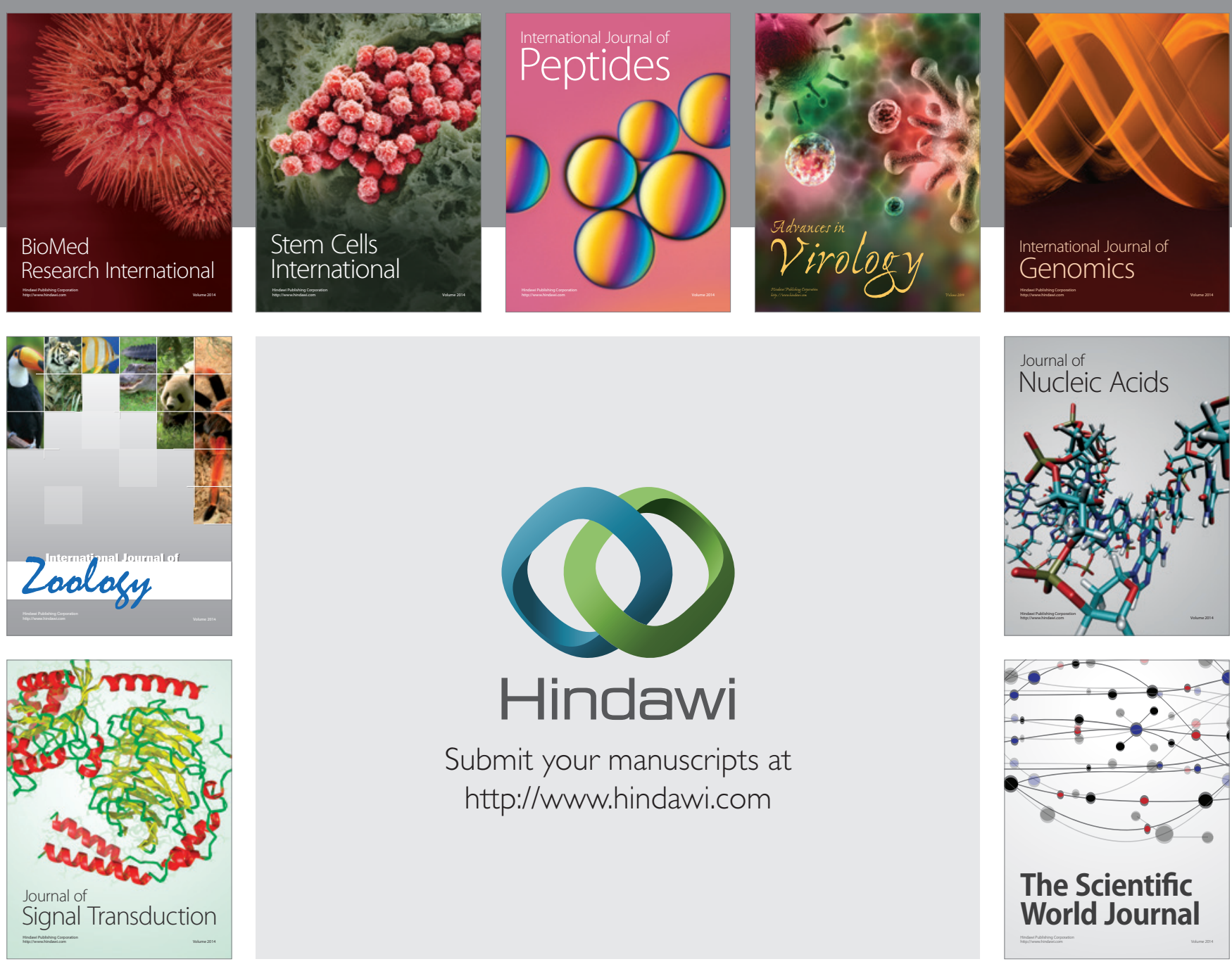

Submit your manuscripts at

http://www.hindawi.com


The Scientific World Journal
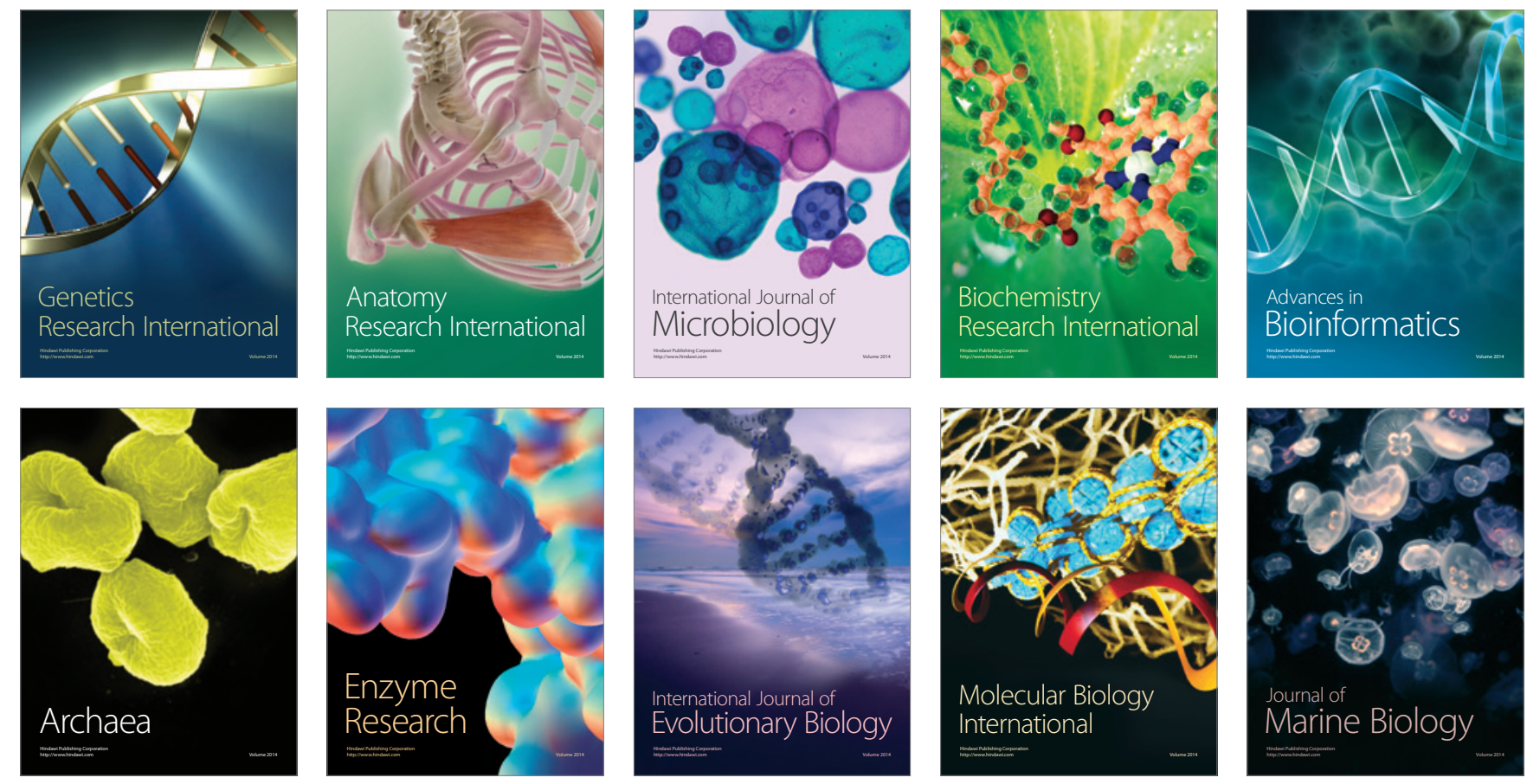